\title{
Reference serving sizes for the Brazilian population: An analysis of processed food labels ${ }^{1}$
}

\author{
Porção de referência para a população brasileira: \\ uma análise considerando rótulos de \\ alimentos industrializados
}

Nathalie KLIEMANN ${ }^{2}$

Marcela Boro VEIROS²

David Alejandro GONZÁLEZ-CHICA²

Rossana Pacheco da Costa PROENÇA²

A B S T R A C T

\section{Objective}

To compare serving sizes reported on processed food labels with reference serving sizes according to nutrition labeling legislation and the "Food Guide for the Brazilian Population".

\section{Methods}

This cross-sectional study analyzed the labels of 2,072 processed foods in a supermarket of Florianópolis, Santa Caratina, Brazil. The foods were classified according to the Brazilian food labeling legislation. Central tendency and variability values were calculated for the serving sizes and energy values reported on the labels, as well as the ratio between the reported and reference energy value. The Spearman correlation test was performed between the reference serving size and the reference energy density, and also between the reference serving size and energy density of each study food.

\section{Results}

Nutrition labeling and the Food Guide presented reference servings with different sizes and energy values. The serving sizes reported on the labels did not follow either of the references and presented heterogeneous values, with a maximum range of 55-240 $\mathrm{g}$ among ready and semi-ready pre-prepared dishes. The reported energy values were between 0.1 times smaller and 2.4 times larger than the reference values. The reference

\footnotetext{
1 Article based on the master's thesis of N KLIEMANN intitled "Análise das porções e medidas caseiras em rótulos de alimentos industrializados ultraprocessados". Universidade Federal de Santa Catarina; 2012.

2 Universidade Federal de Santa Catarina, Departamento de Nutrição, Programa de Pós-Graduação em Nutrição. Campus Universitário, Trindade, 88040-900, Florianópolis, SC, Brasil. Correspondência para/Correspondence to: RPC PROENÇA. E-mail: <rossana.costa@ufsc.br>.

Support: Coordenação de Aperfeiçoamento de Pessoal de Nível Superior.
} 
serving sizes presented a highly inverse correlation with the reference energy density (Spearman coefficient= 0.9 ) and a very low inverse correlation with the energy density of the foods analyzed (Spearman coefficient= 0.2 ).

\section{Conclusion}

This study showed the need for standardizing reference serving size information for the Brazilian population as well as reviewing nutrition labeling legislation in order to standardize the serving sizes reported on labels and to update the reference energy density used to calculate serving sizes.

Indexing terms: Food nutrition education. Food labeling. Industrialized foods. Nutrition policy. Nutritional facts.

\section{RE S U M O}

\section{Objetivo}

Comparar as porções declaradas nos rótulos de alimentos industrializados com as porções de referência da legislação de rotulagem nutricional e do "Guia Alimentar para a População Brasileira".

\section{Métodos}

Estudo transversal que analisou os rótulos de 2072 alimentos industrializados em um supermercado de Florianópolis, Santa Catarina. Os alimentos foram classificados de acordo com a legislação brasileira de rotulagem nutricional. Foram calculados valores de tendência central e de variabilidade para porção e valor energético declarados nos rótulos, além da razão entre o valor energético declarado e de referência. Teste de Correlação de Spearman foi realizado entre porção e densidade energética de referência e entre porção de referência e densidade energética de cada alimento analisado.

\section{Resultados}

A rotulagem nutricional e o Guia Alimentar apresentaram porções de referência com tamanhos e valores energéticos diferentes. As porções declaradas nos rótulos não seguiram nenhuma das referências e apresentaram valores heterogêneos, com amplitude máxima de 55-420 g entre pratos preparados prontos e semiprontos. Os valores energéticos declarados foram de 0,1 vez menor a 2,4 vezes maiores do que os valores de referência. As porções de referência da rotulagem apresentaram correlação inversa alta com a densidade energética de referência (Coeficiente de Spearman=-0,9), e muito baixa com a densidade energética dos alimentos analisados (Coeficiente de Spearman=-0,2).

\section{Conclusão}

Evidenciou-se a necessidade de padronização das informações sobre porção de referência para a população brasileira, assim como de fiscalização e revisão da legislação de rotulagem nutricional a fim de uniformizar as porções declaradas nos rótulos e atualizar a densidade energética de referência usada para o cálculo das porções.

Termos de indexação: Educação alimentar nutricional. Rotulagem de alimentos. Alimentos industrializados. Política nutricional. Informação nutricional.

\section{NTRODUCTION}

Obesity is currently considered a major public health problem and affects large parts of the world ${ }^{1}$. The main causes of obesity include changes in dietary and physical activity patterns, especially an increase in the consumption of processed foods as well as the size of the portions consumed ${ }^{2-5}$.
Studies have indicated that obesity and various other chronic diseases can be prevented through public policies and actions in the food environment ${ }^{1,6}$. A healthy environment should promote and facilitate healthier food and serving size choices $^{2-5}$. Examples of population-based strategies include food guides for the public and nutrition labeling of foods. Such measures have been promoted by the World Health Organization 
(WHO) in the 2004 "Global Strategy on Diet, Physical Activity and Health" ${ }^{3}$. The WHO has kept this recommendation in its "Global Action Plan for the Prevention and Control of Noncommunicable Diseases 2013-2020"7.

In Brazil, nutrition labeling and the "Food Guide for the Brazilian Population" have emerged with the aim of promoting healthy food choices and appropriate serving sizes. The Brazilian nutrition labeling legislation ${ }^{8,9}$ has been drafted and harmonized with other Mercosul countries ${ }^{10,11}$ and reference food serving sizes have been defined to be reported on food labels. Along the same lines, the "Food Guide for the Brazilian Population" also defines reference serving sizes for the public in order to guide people in making healthier food choices ${ }^{12}$.

In both policies, the reference serving sizes are defined based on a diet of 2,000 kcal. In this way, food groups have been defined and the number of servings per day and the reference energy value of each serving have been set for each group ${ }^{8,12}$. In addition, serving sizes in grams or millimeters ( $\mathrm{g}$ or $\mathrm{mL}$ ) have been defined for most foods ${ }^{8,12}$. However, the nutrition labeling legislation allows the serving sizes reported on labels to be up to $30 \%$ larger or smaller than the reference serving size $e^{8-9}$.

Studies have suggested that the lack of serving size standardization on food labels among similar kinds of food products can complicate comparison and, as a result, food choices 2,13-14. Furthermore, according to Monteiro \& Cannon ${ }^{15}$, an increase has been observed in the production and consumption of high-energy ultra-processed foods in Brazil as well as a trend towards reformulating these foods in order to reduce their sodium, trans fat, and energy content so that they can be advertised as healthy. However, considering the change in the energy standards of processed foods ${ }^{15}$, it is assumed that the reference serving sizes ( $\mathrm{g}$ or $\mathrm{mL}$ ), when reported on nutrition labels of the processed foods currently available on the Brazilian market, may not match the reference energy values. Furthermore, it is suggested that such issues can compromise the use of this information as a reference for consumption by the public.

Thus, in light of the importance of coherent educational strategies to control the serving sizes consumed by the population ${ }^{2}$, this study analyzed the compliance (in grams/ millimeters and energy value) of the servings reported on processed food labels with the reference serving sizes according to Brazilian nutrition labeling legislation and the "Food Guide for the Brazilian Population".

\section{METHODS}

This was a descriptive and analytical crosssectional study. The data was collected in a large supermarket in Florianópolis (SC), Brazil. The selection of the study's location was intentional. We chose a supermarket that sells a national range of processed foods and belongs to one of the ten largest supermarket chains in Brazil, according to a survey by the Brazilian Supermarket Association in $2013^{16}$. To participate in the study, the free and clear consent of the supermarket managers was obtained.

The sample consisted of 2,072 processed foods that were available for sale during the data collection period and that met the selection criteria explained below.

The inclusion criteria were all the processed foods included in the food list created by Silveira ${ }^{17}$ classified as processed or ultraprocessed ${ }^{15}$. Processed foods are considered to be those that are derived directly from natural foods and converted into less perishable and more palatable and attractive food products through the addition of salt, sugar and/or fat and the use of techniques such as roasting and smoking. Ultraprocessed foods are those that are ready- or semiready-to-eat and consist partially or entirely of industrial ingredients. These foods have low nutritional value and high amounts of energy, simple carbohydrates, sodium and trans and/or saturated fats ${ }^{15}$. We chose this classification 
because it includes foods that are forming a growing part of the Brazilian diet ${ }^{18-20}$.

Exclusion criteria: all concentrated, powdered, dehydrated and/or mixed foods that require reconstitution by adding other ingredients. Processed foods in which the reference serving size according to the Brazilian legislation ${ }^{8}$ was defined based on household measurements or according to the food's nutritional profile. Bakery products prepared and packaged by the supermarket itself, as the nutrition labeling of products sold without packaging or with protective packaging is not mandatory.

Data collection was done by dietitians and trained nutrition students during two consecutive weeks in August 2011. The instrument used for data collection had been previously tested in a pilot study. The instrument included the following information: type of processed food, flavor, total weight ( $\mathrm{g}$ or $\mathrm{mL}$ ), brand, origin (location where the food was produced), serving size ( $\mathrm{g}$ or $\mathrm{mL}$ ), household measurement and energy value per serving. Magnifying glasses were available during the data collection to better view the nutritional information and plastic gloves were provided to handle chilled and/or frozen processed foods.

Variations of the same processed food available in packages of different sizes were recorded as new products, as not all of them had identical serving sizes.

Information was collected on reference serving size in energy value and in grams or milliliters according to Brazilian nutritional labeling legislation 8 and the "Food Guide for the Brazilian Population" 12 .

The collected data were entered into two separate databases and were subsequently checked for errors and validated in EpiData ${ }^{\circledR}$ version $3 \cdot 1$.

The processed foods analyzed were divided into six groups and 38 subgroups with the same reference serving size, according to Resolução da Diretoria Colegiada (RDC) n 359/ $2003^{8}$.
Group A: Composed of bakery products, cereals, legumes, roots, tubers, and their derivatives, including the following subgroups: dry pasta (instant noodles); fresh pasta (with or without filling); fresh dough for pastries and wraps; pizza dough; chilled or frozen dough without filling (e.g. cheese bread); salty crackers with or without filling; pre-fried and/or frozen tubers and cereals (e.g. fried potatoes, polenta and cassava); breakfast cereals 1 ( $\leq 45$ g per cup); breakfast cereals 2 (>45 g per cup); cereal- and flour-based snacks (e.g. potato chips, potato sticks, shoestring potatoes and ice cream cones); ready-made flour; packaged processed breads; toast; popcorn; chilled and frozen foods with filling; and cakes and similar products with or without filling.

Group B: Composed of milk and dairy products, including the following subgroups: dairy drinks, yogurt and fermented milk; cottage, nonfat ricotta, minas, nonfat soft and petit-Suisse cheese; grated cheese; ricotta, semi-hard, white, soft and cream cheese; and dairy desserts.

Group C: Composed of meats and eggs, including the following subgroups: meatballs and hamburger; patés; and meat pastries.

Group D: Composed of oils, fats and oilseeds, including the following subgroups: oilseeds (sweet and salty) and whipped cream.

Group E: Composed of sugars and products that provide energy from carbohydrates and fats, including the following subgroups: chocolates and similar sweets; chocolate confections (e.g. granulated chocolate); soft and peanut sweets (e.g. creamy sweets); sweet preparation mixtures, cake and pie frosting and ice cream syrup; cookies with or without filling; mass or individual ice creams (e.g. ice cream bars and popsickles); and candies, lollipops and lozenges.

Group F: Composed of pre-prepared dishes, including only one subgroup: ready and semi-ready pre-prepared dishes (e.g. refrigerated and frozen dishes; pizza; frozen sandwiches and pies; and non-refrigerated and vacuum-sealed ready-made dishes). 
In the descriptive analysis of the data, we initially compared the reference serving sizes of the nutrition labeling legislation ${ }^{8}$ with those of the "Food Guide for the Brazilian Population"12. In addition, we calculated the median and range of the serving sizes reported on the labels by food subgroup in order to assess the variability of their sizes. In each food subgroup, we also calculated the median and interquartile range for the reported energy values per serving.

Considering that both Brazilian nutrition labeling legislation ${ }^{8}$ and the "Food Guide for the Brazilian Population"12 have reference energy values per serving for each food group, we calculated the ratio between the energy value reported on the labels and the reference values for each subgroup. Thus, it was possible to assess the agreement between these two parameters (reported energy value and reference values).

The non-parametric Spearman correlation test was performed between reference serving size and energy density, both per $100 \mathrm{~g}$ of each food analyzed and per $100 \mathrm{~g}$ of the reference value in the nutrition labeling legislation. This analysis made comparison possible between the theoretical energy density used by the legislation to calculate serving size and the energy density of the foods analyzed in this study. This study included only products with serving sizes defined by law in grams or milliliters.

To analyze the serving sizes ( $\mathrm{g}$ or $\mathrm{mL}$ ) reported on labels in relation to the reference values, the foods were classified into five groups. This classification was done according to the reference serving size under Brazilian law, following the criteria presented in Table 1. However, we have not included the foods in Group $F$ because these foods do not have a reference serving size in grams or milliliters.

\section{RESULTS}

Information was collected from the nutrition labels on 2,072 processed foods. In the comparative analysis between the reference serving sizes under Brazilian law and those of the "Food Guide for the Brazilian Population", we observed that although both use a 2,000 kcal diet as a basis, there were differences between these documents. There were disagreements in the classification of foods into groups as well as in the energy value of the serving sizes, as can be seen in Table 2. Agreement was observed only in the serving sizes of the 'cereals, tubers, roots and derivatives' and 'fruits and natural fruit juices' groups. Beans were considered to be a separate group only in the "Food Guide for the Brazilian Population" 12 , as the nutrition labeling legislation ${ }^{8}$ included beans in the cereals group. Reference value for ready- and semi-ready-to-consume dishes were not defined in either of the two documents analyzed ${ }^{8,12}$.

In regard to serving sizes in grams or milliliters, we found that the Food Guide ${ }^{12}$ defined serving sizes by food type and not by food group, as the nutrition labeling legislation $\mathrm{did}^{8}$. For example, cakes with different flavors had different serving sizes in the Food Guide - e.g. the serving

Table 1. Classification of serving sizes ( $\mathrm{g}$ or $\mathrm{mL}$ ) reported on labels in relation to reference serving sizes under Brazilian food labeling law.

\begin{tabular}{llc}
\hline Classification $^{1}$ & \multicolumn{1}{c}{ Meaning } & Compliance with law $^{2}$ \\
\hline$<70 \%$ & Serving size smaller than $70 \%$ of recommended serving size $(\mathrm{g}$ or $\mathrm{mL})$ & Inadequate \\
$70-99 \%$ & Serving size up to $30 \%$ smaller than recommended serving size $(\mathrm{g} \mathrm{or} \mathrm{mL})$ & Adequate \\
$100 \%$ & Serving size equal to recommended serving size $(\mathrm{g}$ or $\mathrm{mL})$ & Adequate \\
$101-130 \%$ & Serving size up to $30 \%$ larger than recommended serving size $(\mathrm{g}$ or $\mathrm{mL})$ & Adequate \\
$>130 \%$ & Serving size larger than $130 \%$ of the recommended serving size $(\mathrm{g} \mathrm{or} \mathrm{mL})$ & Inadequate \\
\hline
\end{tabular}

Note: ${ }^{1}$ Classification of serving size in $\mathrm{g}$ or $\mathrm{mL}$ reported on the label in relation to the legislated reference serving size. ${ }^{2}$ Resolução da Diretoria Colegiada n $359 / 2003^{8}$. 
Table 2. Comparison between reference serving sizes, in energy value, under Brazilian nutritional labeling law and according to the "Food Guide for the Brazilian Population".

\begin{tabular}{lcc}
\hline \multirow{2}{*}{ Food group } & \multicolumn{2}{c}{ Reference energy value per serving (number of servings per day) ${ }^{\#}$} \\
\cline { 2 - 3 } & $\mathrm{RDC} \mathrm{n}^{\circ} 359 / 2003$ & Food Guide for the Brazilian Population \\
\hline Cereals, tubers, roots, and derivatives & $150 \mathrm{kcal}(6)$ & $150 \mathrm{kcal}(6)$ \\
Vegetables & $30 \mathrm{kcal}(3)$ & $15 \mathrm{kcal}(3)$ \\
Fruits and natural fruit juices & $70 \mathrm{kcal}(3)$ & $70 \mathrm{kcal}(3)$ \\
Milk and derivatives & $125 \mathrm{kcal}(2)$ & $120 \mathrm{kcal}(3)$ \\
Meats and eggs & $125 \mathrm{kcal}(2)$ & $190 \mathrm{kcal}(1)$ \\
Oils, fats, and oilseeds & $100 \mathrm{kcal}(2)$ & $73 \mathrm{kcal}(1)$ \\
Sugar and sweets & $100 \mathrm{kcal}(1)$ & $110 \mathrm{kcal}(1)$ \\
Beans & Assigned to the cereals group & $55 \mathrm{kcal}(1)$ \\
Sauces, pre-prepared seasonings, broths, soups and & No recommendation & No recommendation \\
pre-prepared meals & & \\
\hline
\end{tabular}

Note: "Based on a diet of 2,000 kcal.

RDC: Resolução da Diretoria Colegiada n 359/2003.

size was $30 \mathrm{~g}$ for carrot cake and $50 \mathrm{~g}$ for banana cake. However, under the nutrition labeling legislation, all cake types and flavors had the same reference serving size $(60 \mathrm{~g})$.

Table 3 shows the variability of serving size and energetic value per serving reported on the food labels analyzed. It also presents the ratios between the reported energy values and the reference values. The serving size analysis found that the median serving sizes of 28 subgroups $(83.3 \%)$ were equal to the legislated reference values. However, serving size standardization (in which all food products have declared serving sizes equal to those recommended by law) was found in only six food subgroups (17.6\%), five of which $(14.7 \%)$ belong to Group A. The 28 remaining subgroups varied in reported serving sizes, with a minimum range of 21-30 $\mathrm{g}$ among salty crackers and a maximum range of 55-420 g among ready- and semi-ready-to-consume dishes. The greatest variations were found in the following subgroups: ready- and semi-ready-toconsume dishes; meatballs and hamburgers; meat preparations with flour and bread; and dairy drinks, yogurt and fermented milk.

Regarding energy value per serving, we observed that five food subgroups had median values $(r=1.0)$ that agreed with the reference values defined by the legislation ${ }^{8}$ and/or the Food
Guide for the Brazilian Population ${ }^{12}$. However, only three of these subgroups $(r=1.0)$ agreed with both references. Table 3 also shows that the reported energy value per serving was less than the reference value $(r<1.0)$ in the legislation ${ }^{8}$ and Food Guide ${ }^{12}$ in $58 \%$ and $62 \%$ of the assessed subgroups, respectively. It should be noted that the patés and grated cheese subgroups had reported energy values that were 0.1 and 0.4 times smaller than the reference values, respectively. Reported energy value per serving was greater than the reference value $(>1.0)$ in $28 \%$ and $22 \%$ of the subgroups in relation to the legislation ${ }^{8}$ and the Food Guide ${ }^{12}$, respectively. The fresh pasta and dry pasta groups stand out as their reported energy values were 1.8 and 2.4 times greater than the reference values, respectively.

A high inverse correlation was found between the reference energy density (per 100 g) and the reference serving size established under Brazilian nutrition labeling legislation, as shown in Figure 1.

However, a low inverse correlation was found between legislated reference serving size and energy density (per $100 \mathrm{~g}$ ) of the foods analyzed, as shown in Figure 2. In Figure 2, it can be seen that above the curve, there are processed foods that have large serving sizes defined by law, 
Table 3. Description of serving size ( $\mathrm{g}$ or $\mathrm{mL}$ ) and energy value per serving reported on labels and the ratio between reported energy values and the reference values under Brazilian law and according to the "Food Guide for the Brazilian Population". Florianópolis (SC), Brazil, 2011.

\begin{tabular}{|c|c|c|c|c|c|c|c|c|c|}
\hline \multirow[t]{2}{*}{ Group } & \multirow[t]{2}{*}{ Food subgroup } & \multirow[t]{2}{*}{$\mathrm{n}$} & \multirow{2}{*}{$\begin{array}{l}\text { Reference } \\
\text { serv. size } \\
\text { (g or } \mathrm{mL} \text { ) }\end{array}$} & \multicolumn{2}{|c|}{$\begin{array}{l}\text { Reported serv. size } \\
\quad \text { (g ou } \mathrm{mL} \text { ) }\end{array}$} & \multicolumn{2}{|c|}{$\begin{array}{l}\text { Reported energy value } \\
\text { per serving (kcal) }\end{array}$} & \multicolumn{2}{|c|}{$\begin{array}{c}\text { Ratio between } \\
\text { median energy value } \\
\text { and reference values }\end{array}$} \\
\hline & & & & Median & n Range & Median & IQR & Law $^{1}$ & FGBP \\
\hline \multirow{16}{*}{ A } & Dry pasta & 67 & 80 & 85( & $(30.0 ; 109.0)$ & 364 & $(271 ; 392)$ & 2.4 & 2.4 \\
\hline & Fresh pasta with or without filling & 48 & 100 & 100( & $(50.0 ; 160.0)$ & 275 & $(241 ; 293)$ & 1.8 & 1.8 \\
\hline & Fresh dough for pastries and wraps & 23 & 30 & 30( & $(30.0 ; 60.0)$ & 90 & $(86 ; 95)$ & 0.6 & 0.6 \\
\hline & Pizza dough & 10 & 40 & 40 & $(25.5 ; 40.0)$ & 113 & $(112 ; 117)$ & 0.8 & 0.8 \\
\hline & Chilled or frozen without filling & 7 & 50 & 50 & $(-)$ & 145 & $(139 ; 152)$ & 1.0 & 1.0 \\
\hline & Crackers & 92 & 30 & 30( & $(21.0 ; 30.0)$ & 124 & $(111 ; 135)$ & 0.8 & 0.8 \\
\hline & $\begin{array}{l}\text { Pre-fried and/or frozen tubers and } \\
\text { cereals }\end{array}$ & 11 & 85 & 85( & $(70.0 ; 100.0)$ & 123 & $(106 ; 155)$ & 0.8 & 0.8 \\
\hline & Breakfast cereals 1 ( $\leq 45$ g per cup) & 22 & 30 & 30( & $(20.0 ; 30.0)$ & 110 & $(109 ; 113)$ & 0.7 & 0.7 \\
\hline & Breakfast cereals 2 (>45 g per cup) & 39 & 40 & 40 & $(-)$ & 158 & $(138 ; 163)$ & 1.1 & 1.1 \\
\hline & Cereal- and flour-based snacks & 107 & 25 & 25( & $(10.0 ; 40.0)$ & 127 & $(116 ; 141)$ & 0.8 & 0.8 \\
\hline & Pre-prepared flour & 6 & 35 & 35 & $(-)$ & 142.5 & $(134 ; 150)$ & 1.0 & 1.0 \\
\hline & Packaged bread, sliced and unsliced & 101 & 50 & 50 & $(40.0 ; 75.0)$ & 122 & $(115 ; 138)$ & 0.8 & 0.8 \\
\hline & Toast & 26 & 30 & 30 & $(-)$ & 112 & $(105 ; 119)$ & 0.7 & 0.7 \\
\hline & Popcorn & 31 & 25 & 25 & $(-)$ & 98 & $(94 ; 102)$ & 0.7 & 0.7 \\
\hline & Chilled or frozen with filling & 12 & 40 & 45 & (30.0; 120.0) & 134.5 & $(121 ; 204)$ & 0.9 & 0.9 \\
\hline & Cakes and similar foods & 55 & 60 & 60( & $(30.0 ; 60.0)$ & 219 & $(161 ; 247)$ & 1.5 & 1.5 \\
\hline \multirow{5}{*}{ B } & $\begin{array}{l}\text { Dairy drinks }{ }^{\dagger} \text {, yogurt and fermented } \\
\text { milk }^{\dagger}\end{array}$ & 186 & 200 & 180( & $(75.0 ; 300.0)$ & 112.5 & $(63 ; 157)$ & 0.9 & 0.9 \\
\hline & $\begin{array}{l}\text { Cheese: cottage, ricotta, non-fat, } \\
\text { minas, non-fat soft, and petit-Suisse }\end{array}$ & 45 & 50 & 40 & $(30.0 ; 60.0)$ & 64 & $(50 ; 80)$ & 0.5 & 0.5 \\
\hline & Grated cheese & 16 & 10 & 10( & $(10.0 ; 30.0)$ & 46 & $(42.5 ; 100)$ & 0.4 & 0.4 \\
\hline & $\begin{array}{l}\text { Cheese: ricotta, semi-hard, white, soft, } \\
\text { cream cheese }\end{array}$ & 184 & 30 & 30( & $(20.0 ; 120.0)$ & 99,5 & $(80,5 ; 110)$ & 0.8 & 0.8 \\
\hline & Dairy desserts & 20 & 120 & 105 & $(40.0 ; 200.0)$ & 128 & $(101 ; 152)$ & 1.0 & 1.1 \\
\hline \multirow{3}{*}{ C } & Meatballs and hamburger patty & 25 & 80 & 80( & $(56.0 ; 420.0)$ & 149 & $(101 ; 178)$ & 1.2 & 0.8 \\
\hline & Patês & 24 & 10 & 10( & $(10.0 ; 100.0)$ & 24.5 & $(19 ; 220)$ & 0.2 & 0.1 \\
\hline & Breaded meat preparations & 49 & 130 & 130( & $(30.0 ; 275.0)$ & 245 & $(165 ; 305)$ & 2.0 & * \\
\hline \multirow{2}{*}{ D } & Oilseeds & 31 & 15 & 15( & $(15.0 ; 25.0)$ & 87 & $(75 ; 92)$ & 0.9 & 1.2 \\
\hline & Whipped cream & 5 & 20 & 20( & $(7.0 ; 20.0)$ & 59 & $(50 ; 60)$ & 0.6 & 0.8 \\
\hline \multirow{7}{*}{$\mathrm{E}$} & Chocolates and similar products & 159 & 25 & 25( & $(10.4 ; 41.0)$ & 133 & $(123 ; 138)$ & 1.3 & 1.2 \\
\hline & Chocolate confections & 23 & 25 & 25( & $(10.0 ; 25.0)$ & 97 & $(40 ; 117)$ & 1.0 & 0.9 \\
\hline & Dough and peanut sweets & 26 & 20 & 20( & $(15.0 ; 40.0)$ & 104.5 & $(95 ; 115)$ & 1.0 & 1.0 \\
\hline & $\begin{array}{l}\text { Frosting and syrup for cakes, pies, and } \\
\text { ice cream }\end{array}$ & 15 & 20 & 20 & $(-)$ & 56 & $(56 ; 63)$ & 0.6 & 0.5 \\
\hline & Cookies with or without filling & 275 & 30 & 30( & $(14.0 ; 100.0)$ & 143 & $(131 ; 152)$ & 1.4 & 1.0 \\
\hline & Soft and individual ice creams & 157 & 60 & 60( & $(40.0 ; 90.0)$ & 114 & $(103 ; 135)$ & 1.1 & 1.0 \\
\hline & Candies, lollipops and lozenges & 60 & 20 & 20( & $(2.0 ; 20.0)$ & 79 & $(75 ; 80)$ & 0.8 & 0.7 \\
\hline $\mathrm{F}$ & Ready and semi-ready prepared dishes & 115 & - & 145( & $(55 ; 420)$ & 335 & $(175 ; 401)$ & * & * \\
\hline
\end{tabular}

Note: 'Serving size in mL. ${ }^{1}$ Resolução da Diretoria Colegiada n 359/20038. Dietary Guide for the Brazilian Population ${ }^{12}$. ${ }^{*}$ There is no reference value. Group A: Bread products, cereals, legumes, roots, tubers and their derivatives. Group B: Milk and derivatives. Group C: Meats and eggs. Group D: Oils, fats and oilseeds. Group E: Sugars and products that provide energy from carbohydrates and fats.

IQR: Interquartile Range; FGBP: Food Guide for the Brazilian Population. 


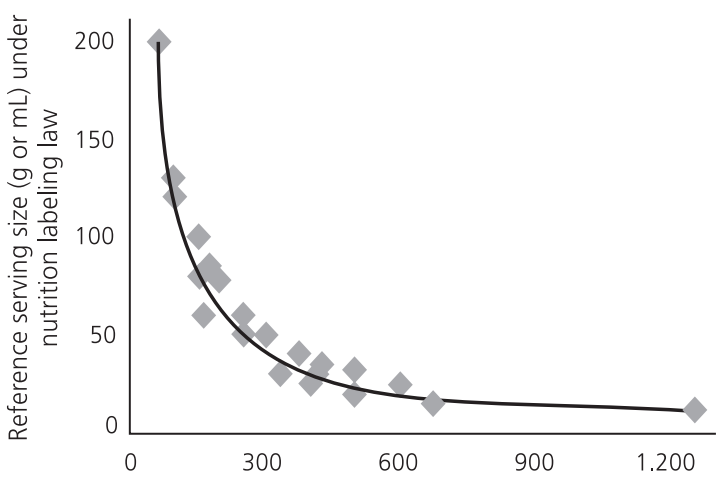

Reference energy density ( $\mathrm{kcal} / 100 \mathrm{~g}$ ) under nutrition labeling law

Figure 1. Relation between reference serving size ( $\mathrm{g}$ or $\mathrm{mL}$ ) and reference energy density ( $\mathrm{kcal} / 100 \mathrm{~g})$ established by Brazilian nutrition labeling law. Florianópolis (SC), Brazil, 2011.

Note: Spearman correlation; Coefficient=-0.9; $\mathrm{N}=1,957$.

yet present high energy density. It can also be observed that, if all the foods reported the reference serving size, their energy value would not be the same as that established by law. This data indicates that the energy density of the analyzed foods is different from the theoretical energy density that was used to calculate serving sizes for nutrition labeling legislation.

In analyzing the compliance of reported serving sizes with the law, it was found that $72.4 \%$ (Confidence Interval of 95\% $95 \% \mathrm{Cl}=70.3 ; 74.3)$ of the foods had serving sizes equal to the reference value. Among the foods that did not exactly match the reference serving size, $10.1 \%(95 \% \mathrm{Cl}=8.7 ; 11.5)$ and $3.9 \%$ $(95 \% \mathrm{Cl}=3.0 ; 4.8)$ still complied with the law, as they were $70-99 \%$ and $101-130 \%$ in agreement, respectively. The remaining foods did not comply with the law, as $9.3 \%(95 \% \mathrm{Cl}=8.0 ; 10.6)$ had serving sizes that were too small and $4.1 \%$ $(95 \% \mathrm{Cl}=3.2 ; 5.0)$ had serving sizes that were too large.

\section{DISCUSSION}

This study's results show that the reference serving sizes under the Brazilian nutrition labeling

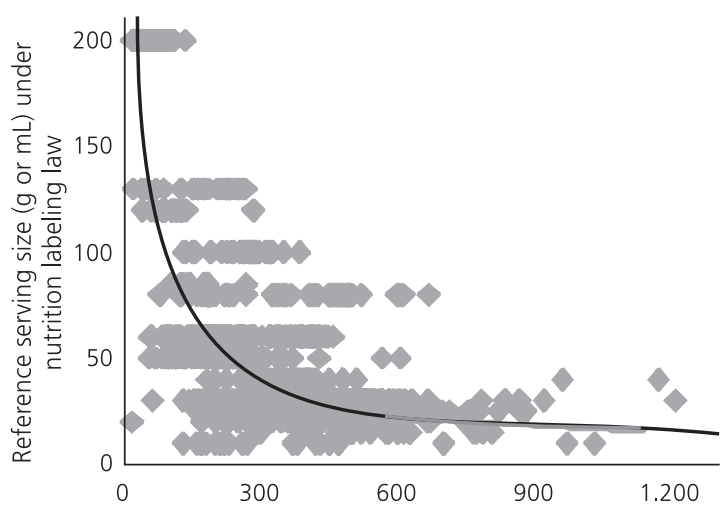

Energy density (kcal/100 g) of the processed foods analyzed

Figure 2. Relation between reference serving size ( $\mathrm{g}$ or $\mathrm{mL}$ ) under Brazilian nutrition labeling law and energy density (kcal/100 g) of the processed foods analyzed. Florianópolis (SC), Brazil, 2011.

Note: Spearman correlation; Coefficient $=-0.2 ; \mathrm{N}=1,954$.

legislation 8 and the "Food Guide for the Brazilian Population" 12 are different for some food groups while the serving sizes reported on labels do not generally follow either of these references. Reported serving sizes were also heterogeneous even among foods of the same group.

We point out that there are currently two official documents that provide different reference serving sizes for the Brazilian population, even though both are based on a 2,000 kcal diet ${ }^{8,12}$. The disagreement between the serving sizes defined by these two public policies is also found in other countries such as the United States and Canada. In these countries, this difference is justified by the different purposes of the policies, as serving sizes on labels represent the amount of the food that is typically consumed while serving sizes in the Food Guides are recommended amounts ${ }^{2,12,21}$. However, this justification is not applicable in Brazil since both documents have the same goal of promoting the selection of healthy foods in appropriate amounts.

Furthermore, research has shown that the disagreement between the serving size on nutritional labels and that of the Food Guide can cause confusion ${ }^{22}$ or lead consumers to underestimate serving sizes ${ }^{23,24}$. In addition, 
several studies analyzed by Abramovitch et al. ${ }^{25}$ have shown that merely publishing reference serving sizes in food guides does not seem to be sufficient to educate the public about consuming food in appropriate amounts, and that other educational strategies are necessary. In this sense, the authors understand that agreement between these two documents could facilitate nutrition education programs for the public ${ }^{26,27}$.

The present study also found that the serving sizes reported on the labels did not conform with the reference serving sizes in grams or milliliters, nor with the reference energy values $^{8,12}$. Variation was observed in reported serving sizes among foods of the same group and the greatest range was found in the ready and semi-ready pre-prepared dishes group. This group is also the one that does not have a reference serving size in Brazil - neither in the labeling legislation ${ }^{8}$ nor in the Food Guide ${ }^{12}$.

According to a study conducted in Ireland, food guides rarely define reference serving sizes for the public for foods with high energy values, such as ready-to-consume dishes. This is due to the fact that such foods do not belong in a healthy diet. In these cases, there are merely warnings that such foods should be consumed sporadically or in small portions ${ }^{22}$. Even so, the terms 'sporadically' and 'small portions' may have no practical significance, as their interpretation is subjective. Furthermore, high consumption of these foods by Brazilians ${ }^{20}$ has been linked to rising rates of chronic diseases ${ }^{15,28}$. Therefore, it is suggested that defining reference serving sizes for these foods can be a means of promoting nutrition education and improving the quality of information for consumers.

The lack of standardization in the reporting of serving size in nutrition labeling was also reported in a Brazilian study that analyzed 142 labels for yogurt, dairy drinks and fermented milk sold in the state of Minas Gerais and found a range of serving sizes from 100 to $200 \mathrm{~g}$ (the legislated reference serving size is $200 \mathrm{~g})^{29}$. The variability of the foods analyzed in the present study was even greater, reaching a range of 75 to $300 \mathrm{~g}$. It is suggested that such a difference could result from a difference in sample size, as the present study used a sample that was 31\% larger than that of the Grandi \& Rossi study ${ }^{29}$. Similar results have also been found in studies conducted in other countries where nutrition label information is also presented per serving. In Australia, for example, 1,070 processed foods were analyzed and serving sizes for snacks ranged from $18 \mathrm{~g}$ to $100 \mathrm{~g}$, demonstrating a lack of uniformity ${ }^{13}$. In the United States, research has indicated that the serving sizes reported on labels can vary from $50 \%$ to $200 \%$ of the reference values defined by the Food and Drug Administration (FDA) ${ }^{30,31}$. According to the scientific literature, a lack of serving size standardization can compromise the comparability of processed foods and thus food choices, if this is the only information reported on nutrition labels $13,22,29,32$.

Furthermore, even though Brazilian law allows a variability of $30.0 \%$ more or $30.0 \%$ less than the reference value when reporting serving sizes, the present study found that $13.4 \%$ of the foods analyzed did not comply and exceeded the permitted range, which already seems quite wide. Other studies conducted in Brazil have also found high nonconformity of food labels with the Brazilian law ${ }^{33-36}$. These studies have identified the greatest irregularities on food labels to be those referring to nutrition information ${ }^{33-36}$. Such studies reinforce the recommendation to better regulate the nutrition information provided on food labels.

In addition to the lack of serving size uniformity, low conformity has also been observed in the reported energy value per serving compared to the legislated reference value. This agrees with the findings of Piernas \& Popkin ${ }^{5}$, who elucidated changes in the energy density of American processed foods in 1977-1978 and 2002-2003, mainly among salty snacks, processed fruit juices, French fries, hamburgers, and pizza.

Therefore, it is necessary to review the serving sizes in grams and milliliters defined by 
Brazilian law, so that they reflect on food labels the energy recommendations per serving established by the same legislation. Furthermore, the definition of reference serving sizes per subgroup can explain this result, as foods with different flavors can have different energy densities. For example, the Food Guide defines different serving sizes for foods with different flavors that belong to the same group. In the case of corn bread and rye bread, for instance, the serving size is $70 \mathrm{~g}$ for the former and $60 \mathrm{~g}$ for the latter ${ }^{12}$. Therefore, it is suggested that the nutrition labeling legislation's classification of foods into subgroups also be assessed so that the reference serving sizes reflect reference energy values on food labels. Ferreira \& Lanfer-Marquez ${ }^{37}$ emphasize the importance of updating Brazilian nutrition labeling regulations to incorporate new knowledge and fill in existing gaps in order to strengthen these policies as a strategy for reducing obesity rates.

Despite a lack of studies evaluating the effects of defining reference serving sizes for the population, Faulkner et al. ${ }^{22}$ point out that it is important that reference serving sizes be established and effectively disclosed to consumers. Researchers also point to the need for establishing more realistic serving sizes than the public currently customarily consumes ${ }^{2,22}$. It is noteworthy that the scientific community considers reference serving sizes and their respective household measurements to be essential to understanding the applicability of nutrition labeling 22,38. However, studies also emphasize that it is vital to equip the Brazilian consumer to know how to interpret nutrition labels. Thus, such information can potentially play an educational role and facilitate food choices ${ }^{39,40}$.

Finally, it is recommended that nutrition information per $100 \mathrm{~g}$ be included together with serving size information. According to some authors, the inclusion of such information could facilitate consumer analysis of nutrient quantities present in foods as well as comparisons between foods $s^{41,42}$.
Limitations of this study include using only information from labels and not performing physical or chemical analyses on the foods or even weighing them. Even so, we analyzed the information that is available to consumers on labels, which is the only information that is currently available to guide their food choices at the time of purchase. Therefore, considering the rights of the consumer and the goals of labeling as a public health policy, the reliability of this information should be guaranteed by manufacturers and be subject to oversight to ensure compliance with the law. Another of this study's potential limitations was the inclusion of processed foods from a single supermarket. However, this store is part of a large supermarket chain and many of the processed foods analyzed are sold throughout the country.

\section{CONCLUSION}

This study showed a lack of standardization in reference serving size information for Brazilian consumers. There are differences between the serving sizes established by the "Food Guide for the Brazilian Population and Brazilian" nutrition labeling legislation and those reported on processed food labels. In addition, we observed that not all foods reported the legislated reference serving sizes, demonstrating serving size variability on labels. Finally, we point out that the energy density used to calculate reference serving sizes in the legislation is different from that found on the food labels we analyzed.

Therefore, we conclude that it is necessary to review Brazilian nutrition labeling legislation in regard to the food classification, reference serving sizes and energy density used. In addition, considering that reference serving sizes can be different among foods with different flavors due to differences in energy density, we recommend the inclusion of nutritional information per $100 \mathrm{~g}$. Including such information can serve as a strategy for facilitating comparisons between foods and using this information to make food choices. 
Finally, we emphasize the importance of standardizing reference serving size information in the "Food Guide for the Brazilian Population", Brazilian nutrition labeling legislation and on food labels. Such standardization aims to facilitate access to information on reference serving sizes by consumers and the use of this information in public nutrition education programs. Therefore, we suggest reviewing the permitted variation in serving sizes reported on labels, which currently can range from 30\% less to 30\% more than the reference serving size. The data reported here indicate that this range may be too wide, virtually precluding the possibility of comparing similar foods.

Finally, we found that $13 \%$ of the foods analyzed reported serving sizes that did not comply with the legislation despite the wide variability permitted. This seems to point to the need to carefully monitor the information reported on the labels of food products sold in Brazil.

\section{CONTRIBUTORS}

N KLIEMANN helped to conceive, design, and implement the study, analyze and interpret the data, and write the manuscript. DA GONZALEZ-CHICA helped to analyze the data statistically and interpret and discuss the results. MB VEIROS and RPC PROENÇA conceived, designed, coordinated, and supervised the study and the manuscript writing.

\section{REFEREN CES}

1. World Health Organization. Obesity and overweight. Geneva: WHO; 2013 [cited 2013 Jul 4]. Available from: <http://www.who.int/mediacentre/factsheets/ fs311/en/>.

2. Young LR, Nestle M. Expanding portion size in the US marketplace: Implications for nutrition counseling. J Am Diet Assoc. 2003; 103(2):231-4. doi: 10.1053/jada.2003.50027.

3. World Health Organization. Global strategy on diet, physical activity and health. Geneva: WHO; 2004 [cited 2013 Jul 4]. Available from: <http://www. who.int/dietphysicalactivity/strategy/eb11344/ strategy_english_web.pdf>

4. Popkin BM. Global nutrition dynamics: The world is shifting rapidly toward a diet linked with noncommunicable diseases. A J Clin Nutr. 2006; 84(2):289-98.

5. Piernas C, Popkin B. Food portion patterns and trends among U.S. children and the relationship to total eating occasion size, 1977-2006. J Nutr. 2011; 141(6):1159-64. doi: 10.3945/jn.111.138727

6. Malik VS, Willett WC, Hu FB. Global obesity: Trends, risk factors and policy implications. Nat Rev Endocrinol. 2013; 9(1):13-27. doi: 10.1038/ nrendo.2012.199

7. World Health Organization. Follow-up to the Political declaration of the high-level meeting of the general assembly on the prevention and control of non-communicable diseases. Geneva: WHO; 2013 [cited 2013 Jul 4]. Available from: <http:// apps.who.int/gb/ebwha/pdf_files/WHA66/A66_ R10-en.pdf>.

8. Brasil. Ministério da Saúde. Agência Nacional de Vigilância Sanitária. Resolução RDC n 359, de 23 de dezembro de 2003: aprova regulamento técnico de porções de alimentos embalados para fins de rotulagem nutricional. Diário Oficial [da] República Federativa do Brasil. 2003; 26 dez.

9. Brasil. Ministério da Saúde. Agência Nacional de Vigilância Sanitária. Resolução RDC n 360, de 23 de dezembro de 2003. Aprova regulamento técnico o sobre Rotulagem Nutricional de Alimentos Embalados, tornando obrigatória a rotulagem nutricional. Diário Oficial [da] República Federativa do Brasil. 2003; 26 dez.

10. Mercosul. Grupo Mercado Comum. Resolução n 44/03, de 10 de dezembro de 2003. Aprova o regulamento técnico do Mercosul para rotulagem nutricional de alimentos embalados. LII GMC. Montevidéu. 2003; 10 dez. 2003a.

11. Mercosul. Grupo Mercado Comum. Resolução $n^{\circ}$ 46/03, de 10 de dezembro de 2003. Aprova o regulamento técnico do Mercosul para rotulagem nutricional de alimentos embalados. LII GMC. Montevidéu. 2003; 10 dez.

12. Brasil. Ministério da Saúde Guia alimentar para a população brasileira: promovendo a alimentação saudável. Brasília: Ministério da Saúde; 2005 [acesso 2013 jul 4]. Disponível em: <http://dtr2001.saude. gov.br/editora/produtos/livros/pdf/05_1109_M. pdf $>$.

13. Walker KZ, Woods JL, Rickard CA, Wong CK. Product variety in Australian snacks and drinks: How can the consumer make a healthy choice? Public Health Nutr. 2007; 11(10):1046-53. doi: 10.1017/S1 368980007001462 
14. Instituto Brasileiro de Defesa do Consumidor. Além da conta. Rev IDEC. 2009; 16-2.

15. Monteiro CA, Cannon G. The Impact of Transnational "Big Food" Companies on the South: A view from Brazil. PLoS Med. 2012; 9(7):1-5. doi: 10.1371/journal.pmed.1001252

16. Associação Brasileira de Supermercados. Ranking ABRAS 2013. Rev SuperHiper. 2013 [acesso em 2013 jul 23]; Disponível em: <http://www. abrasnet.com.br/clipping.php?area=20\&clipping= 35850>.

17. Silveira BM. Informação alimentar e nutricional da gordura trans em rótulos de alimentos industrializados comercializados em um supermercado de Florianópolis [Dissertação]. Universidade Federal de Santa Catarina; 2011

18. Instituto Brasileiro de Geografia e Estatística. Pesquisa de orçamentos familiares 2008-2009: aquisição alimentar domiciliar per capita. Rio de Janeiro: IBGE; 2010 [acesso 2011 mar 11]. Disponível em: <http://www.ibge.gov.br/home/ estatistica/populacao/condicaodevida/pof/2008 _2009_aquisicao/pof20082009_aquisicao.pdf >.

19. Instituto Brasileiro de Geografia e Estatística. Pesquisa de orçamentos familiares 2008-2009: despesas, rendimentos e condições de vida. Rio de Janeiro: IBGE; 2010 [acesso 2011 mar 11]. Disponível em: <http://www.ibge.gov.br/home/ estatistica/populacao/condicaodevida/pof/ 2008_2009_aquisicao/pof20082009_aquisicao. $p d f>$.

20. Instituto Brasileiro de Geografia e Estatística. Pesquisa de orçamentos familiares 2008-2009: análise do consumo alimentar pessoal no Brasil. Rio de Janeiro: IBGE; 2011 [acesso 2012 jan]. Disponível em: <http://www.ibge.gov.br/home/ estatistica/populacao/condicaodevida/pof/2008_ 2009_analise_consumo/default.shtm>.

21. Sibbald B. Canada's nutrition labels: A new world standard? CMAJ. 2003; 168(7):887.

22. Faulkner GP, Pourshahidi LK, Wallace JMW, Kerr MA, McCrorie TA, Livingstone MBE. Serving size guidance for consumers: Is it effective? Proc Nutr Soc. 2012; 71(4):610-21. doi: 10.1017/S002966 5112000766

23. Hogbin MB, Hess MA. Public confusion over food portions and servings. J Am Diet Assoc. 1999; 99(10):1209-11. doi: 10.1016/S0002-8223(99) 00297-7

24. Britten P, Haven J, Davis C. Consumer research for development of educational messages for the MyPyramid Food Guidance System. J Nutr Educ
Behav. 2006; 38(6):S108-S23. doi: 10.1016/j.jneb. 2006.08.006.PMID:17116589

25. Abramovitch SL, Reddigan Jl, Hamadeh MJ, Jamnik VK, Rowan CP, Kuk JL. Underestimating a serving size may lead to increased food consumption when using Canada's Food Guide. Appl Physiol Nutr Metab. 2012; 37(5):923-30. doi: 10.1139/H2012-0 71

26. Earl R, Porter DV, Wellman NS. Nutrition labeling: Issues and directions for the 1990s. J Am Diet Assoc. 1990; 90(11):1599-601.

27. Canadian Food Inspection Agency. Food labelling. Ottawa: Canadian Food Inspection Agency; 2013 [cited 2013 Mar 13]. Available from: <http://www. inspection.gc.ca/english/fssa/labeti/guide/ch6e. shtml\#a6_1)>.

28. World Health Organization. Diet, nutrition and the prevention of chronic diseases. Geneva: WHO; 2003 [cited 2013 Jun 4]. Technical Report Series, n’ 916. Available from: <http://whqlibdoc.who.int/ trs/who_trs_916.pdf>.

29. Grandi AZ, Rossi DA. Avaliação dos itens obrigatórios na rotulagem nutricional de produtos lácteos fermentados. Rev Inst Adolfo Lutz. 2010; 69(1):62-8

30. United States Department of Agriculture. Serving sizes in the food guide pyramid and on the nutrition facts label: What's different and why? Washington (DC): United States Department of Agriculture; 2000 [cited 2013 May 14]. Available from: <http:// www.cnpp.usda.gov/Publications/Nutrition Insights/Insight22.pdf>.

31. Usmanova N, Thor E. Comunicating nutritional information to the global consumer: Adapting to shifting consumer attitudes toward nutrition. Int Food Agrib Man Rev. 2003; 6(2):1-18.

32. Hawley KL, Roberto CA, Bragg MA, Liu PJ, Schwartz $M B$, Brownell KD. The science on front-of-package food labels. Public Health Nutr. 2012; 16(3):430-9. doi: $10.1017 /$ S1368980012000754

33. Smith ACL, Almeida-Muradian LB. Rotulagem de alimentos: avaliação da conformidade frente à legislação e propostas para a sua melhoria. Rev Inst Adolfo Lutz. 2011; 70(4):463-72

34. Câmara MCC, Marinho CLC, Guilam MC, Braga AMCB. A produção acadêmica sobre a rotulagem de alimentos no Brasil. Rev Panam Salud Publica. 2008; 23(1):52-8. doi: 10.1590/\$1020-498920080 00100007

35. Lobanco CM, Vedovato GM, Cano CB, Bastos DHM. Fidedignidade de rótulos de alimentos comercializados no município de São Paulo, SP. Rev 
Saúde Pública. 2009; 43(3):499-505. doi: 10.1590/ S0034-89102009005000020

36. Dias JR, Gonçalves ECBA. Avaliação do consumo e análise da rotulagem nutricional de alimentos com alto teor de ácidos graxos trans. Ciênc Tecnol Aliment. 2009; 29(1):177-82. doi: 10.1590/S010 1-20612009000100027

37. Ferreira AB, Lanfer-Marquez UM. Legislação brasileira referente à rotulagem nutricional de alimentos. Rev Nutr. 2007; 20(1):83-93. doi: 10.1590/S141 5-52732007000100009

38. Albert J. Global patterns and country experiences with the formulation and implementation of food-based dietary guidelines. Ann Nutr Metab. 2007; 51(Suppl 2):S2-S7. doi: 10.1159/000103560

39. Monteiro RA, Coutinho JG, Recine E. Consulta aos rótulos de alimentos e bebidas por freqüentadores de supermercados em Brasília, Brasil. Rev Panam Salud Publ. 2005; 18(3):172-7.

40. Neves AM, Guimarães PIC, Mercon F. Interpretação de rótulos de alimentos no ensino de química. Quím Nova Esc. 2009; 31(1):34-9.

41. Garsetti M, de Vries J, Smith M, Amosse A, RolfPedersen N. Nutrient profiling schemes: Overview and comparative analysis. Eur J Nutr. 2007; 46(2):15-28. doi: 10.1007/s00394-007-2002-7

42. Silveira BM, Gonzalez-Chica DA, Proença RPC. Reporting of trans-fat on labels of Brazilian food products. Public Health Nutr. 2013; 16(12):2156-3. doi: $10.1017 / S 1368980013000050$

Received on: 9/13/2013

Final version on: 3/12/2014

Approved on: 4/15/2014 
